\title{
Evaluation of sticky trap colour for thrips (Thysanoptera) monitoring in pea crops (Pisum sativum L.)
}

\author{
Maria Pobozniak $^{1}$ (D) Krzysztof Tokarz $^{2}$ (D) Kazhymurat Musynov ${ }^{3}$ (D)
}

Received: 17 September 2019 / Accepted: 20 January 2020 / Published online: 1 February 2020

(c) The Author(s) 2020

\begin{abstract}
We compared the effectiveness of three different trap colours (blue, yellow and white) to identify the optimal trap colour for the monitoring of the thrips Frankliniella intonsa, Thrips tabaci, Thrips fuscipennis and Aeolothrips intermedius in the three pea cultivars, namely Polar, Izolda and Tarchalska. The number of captured thrips specimens was significantly affected by trap colour, pea cultivar and interaction between these factors. The two most attractive trap base colours for thrips were blue (peak at $450 \mathrm{~nm}$ ) and yellow (peak at $550 \mathrm{~nm}$ ). Irrespective of the pea cultivar, most $F$. intonsa were captured on the blue and yellow traps. Blue traps were the most attractive to T. fuscipennis and T. tabaci, followed by yellow and white ones, and yellow traps were most attractive to A. intermedius. More thrips were caught on the traps located in the plots with cultivars characterised by a longer growing season Tarchalska and Izolda, which were inhabited by large numbers of thrips. There was a significant interaction effect between trap colour and pea cultivar on the number of caught $F$. intonsa and $T$. fuscipennis in both years and for T. tabaci in 2010. Overall, among the tested trap colours, blue traps were the most effective ones for monitoring thrips in pea fields and could be used as an early detection tool. Yellow traps may be risky because they reduce population densities of the predaceous A. intermedius in pea fields, thus leading to an increase in pest numbers.
\end{abstract}

\section{Keywords Aeolothrips intermedius $\cdot$ Frankliniella intonsa $\cdot$ Thrips tabaci}

\section{Introduction}

Globally, many species of thrips (Thysanoptera) are pests of vegetables, fruits and ornamentals (Lewis 1997). Pea crops can be infested by a number of harmful organisms, among which thrips are a numerous and economically important group (Ferrarezi et al. 2016). Pobozniak (2013) has determined 18 species of thrips on pea crops, of which three herbivorous species (Frankliniella intonsa, Thrips fuscipennis and Thrips tabaci) and one predatory species (Aeolothrips

Maria Pobozniak

maria.pobozniak@urk.edu.pl

1 Department of Plant Protection, Faculty of Biotechnology and Horticulture, University of Agriculture, Al. 29 Listopada 54, 31-425 Kraków, Poland

2 Institute of Plant Biology and Biotechnology, Faculty of Biotechnology and Horticulture, University of Agriculture, Al. 29 Listopada 54, 31-425 Kraków, Poland

3 Department of Plant Protection and Quarantine, Faculty of Agronomy, Kazakh Agrotechnical University S. Seifullin, Pobeda Avenue 62, 010011 Astana, Republic of Kazakhstan intermedius) together accounted for over $95 \%$ of the total number of all detected thrips. Among the known herbivorous thrips species, the onion thrips (T. tabaci) is the primary pest of pea pods (Gaskel 1997; Pobozniak 2013). On pods, the formation of silvery spots, which later turn brown, can be clearly seen, and the pods undergo deformation primarily from the spout and at the base. This damage leads to a reduced yield quality and to a reduction in weight by up to 70-80\%, depending on the pea cultivar (Shelton and North 1987; Pobozniak 2013). At the time of flowering, pea fields are heavily colonised by thrips attracted to flowers, such as the flower thrips ( $F$. intonsa) and the rose thrips (T. fuscipennis). Both species feed on the flowers, sucking the generative organs and parts of the perianth. As a result of their feeding, the flowers show dark, necrotic spots (Ábrahám 2008; Kirk1984). Current control strategies for thrips in pea mainly rely on chemicals, and farmers use different types of insecticides. However, repeated application of chemicals is not a desirable practice, as this could lead to undesirable resistance problems (Sahito et al. 2013; Shelton et al. 2006). To avoid further resistance of this pest, different nonchemical control methods need to be evaluated. For example, 
coloured sticky traps can be a simple, low-cost method and an effective tool for monitoring the presence of insects and their numbers. For the monitoring of the flight activity of $T$. tabaci, blue (Liu and Chu 2004; Trdan et al. 2005b), yellow (Jenser et al. 2001; Teulon and Penman 2012) and white (Kahrer 1992) traps have been proposed, depending on different crops. For Frankliniella occidentalis and $F$. intonsa, mainly blue (Allsopp 2010; Chu et al. 2000; Seo et al. 2006), yellow (Atakan and Canhilal 2004; Lim and Mainali 2009) or white (Hoddle et al. 2002; Mateus and Mexia 1995) colours have been investigated as attractive. Blue-, yellow- and white-coloured sticky traps are commercially available for the control of some insect pests in many countries. However, the use of sticky traps for capturing species of herbivorous insect pests is risky because they may also capture non-targeted predatory insects and reduce their numbers. Thus, the selection of trap colour should also be based on the knowledge of what colour attracts predatory thrips. According to Rőth et al. (2016), the colour of traps used for controlling thrips should ensure a high correlation between the number of captured thrips and the size of their population in the crop. So far, however, there have been only a few studies aimed at correlating insect counts on coloured traps with the extent of infestation of the surrounding crop (Allan and Gillet-Kaufman 2018; Roth et al. 2016). In the present study, we compare the effectiveness of three different trap colours (blue, yellow and white) to identify the optimal trap colour for the early detection and monitoring of harmful thrips with a low number of captured predatory thrips species. We also determine the relationship between the number of thrips captured on traps and those found directly on plants. Our earlier studies (Pobozniak and Swiderski 2011; Pobozniak 2013) indicate that some morphological features and the development phenology of pea cultivars are the main causes for the varying attractiveness of pea cultivars to thrips. For this reason, the attractiveness of coloured traps was compared on three selected pea cultivars to evaluate their impacts on the number of thrips captured on traps. The obtained data may be used for estimating the abundance of thrips feeding on pea plants, which can be helpful in determining the optimal time for pesticide application, thus reducing their usage and avoiding a build-up of pesticide residues in the environment and the food chain.

\section{Materials and methods}

\section{Experimental design}

The colour preference of thrips was investigated in a field of three pea ( $P$. sativum) cultivars with different ripening times, the early cv. Polar, the medium-early cv. Izolda, and the medium-late cv. Tarchalska, from May to mid-July in 2009 and 2010. All pea cultivars used in the study were obtained from the Polish seed companies, namely the Spójnia Breeding and Seed Production Company in Nochowo, PlantiCo Breeding and Seed Production Company in Zielonki Parcela and the Danko Plant Breeding Company in Choryń. Field experiments were set up at the Experimental Station of the Agricultural University in Krakow, located in Mydlniki (near Kraków, southern Poland, $50^{\circ} 04^{\prime} \mathrm{N}, 19^{\circ} 51^{\prime} \mathrm{E}, 207 \mathrm{~m}$ above sea level). The trial was arranged in a completely randomised design with four replications for each of the pea cultivars. The plots, measuring $16 \mathrm{~m}^{2}(4 \times 4 \mathrm{~m})$, were separated by 1 -m-wide paths. Seeds were sown $(250 \mathrm{~kg} / \mathrm{ha})$ in rows, $0.3 \mathrm{~m}$ apart, on 3 April 2009 and 9 April 2010. Plant density was about 120 plants $/ \mathrm{m}^{2}$. The phenological growth stages of the pea cultivars in all growing seasons were recorded on each sampling date and classified according to Feller et al. (1995) and Weber and Bleiholder (1990), as shown in Table 1. Average daily temperature and precipitation data were obtained with HOBO Pro RH/Temp. Sensors (Onset Computer Corp., USA), located at the Experimental Station (Table 1).

\section{Trap reflectance}

Relative trap reflectance was determined from direct measurements underlaboratory conditions, using a portable spectroradiometer with an external integrated sphere (LI-1800, LI-COR Lincoln, Nebraska, USA) in the radiation range of 400-700 nm. Reflectance measurements were conducted on three differently coloured (blue, yellow and white) insect sticky traps in three repetitions (Fig. 1).

\section{Thrips sampling with traps}

Three differently coloured sticky traps (produced by P.P.H. Medchem, Stara Iwiczna, Poland), blue, yellow and white (measuring $10 \times 20 \mathrm{~cm}$ ), were installed $1 \mathrm{~m}$ apart in the middle of each plot. Trap order was random in each collection period, and the traps were attached to a wooden stake so that their bottom edge was $10-15 \mathrm{~cm}$ below the tops of the plants. The traps were monitored and replaced at 4- to 10-day intervals (i.e. sampling period) from the beginning of pea plant emergence (May) until pea harvest (July). Upon the removal of the coloured sticky traps, they were wrapped with clear plastic cling film and transferred to the laboratory to determine thrips number.

\section{Thrips sampling from plants}

Thrips were caught from pea plants using a standard entomological sweep net with a diameter of $35 \mathrm{~cm}$, produced by the Paradox Company in Krakow, Poland. A single sample 
Table 1 Phenological development stages of different pea cultivars and average daily temperature and rainfall totals in the observation periods in the seasons 2009-2010

\begin{tabular}{|c|c|c|c|c|c|c|c|c|c|c|c|}
\hline \multirow{3}{*}{$\begin{array}{l}\text { Year } \\
2009\end{array}$} & \multicolumn{11}{|c|}{ Month and day } \\
\hline & \multicolumn{4}{|l|}{ May } & \multicolumn{4}{|l|}{ June } & \multicolumn{3}{|l|}{ July } \\
\hline & 13 & 17 & 21 & 26 & 02 & 09 & 18 & 26 & 01 & 06 & 10 \\
\hline Polar & $\mathrm{L}$ & $\mathrm{L} / \mathrm{I}$ & $\mathrm{F}^{*}$ & $\mathrm{~F} / \mathrm{P}$ & $\mathrm{P}$ & $\mathrm{P}$ & $\mathrm{P}$ & $\mathrm{P}$ & & & \\
\hline Izolda & $\mathrm{L}$ & $\mathrm{L}$ & $\mathrm{L} / \mathrm{I}$ & $\mathrm{I} / \mathrm{F}$ & $\mathrm{F}$ & $\mathrm{F}^{*}$ & $\mathrm{~F} / \mathrm{P}$ & $\mathrm{P}$ & $\mathrm{P}$ & & \\
\hline Tarchalska & $\mathrm{L}$ & $\mathrm{L}$ & $\mathrm{L}$ & $\mathrm{L} / \mathrm{I}$ & $\mathrm{L} / \mathrm{I}$ & $\mathrm{I} / \mathrm{F}$ & $\mathrm{F}^{*}$ & $\mathrm{~F} / \mathrm{P}$ & $\mathrm{P}$ & $\mathrm{P}$ & $\mathrm{P}$ \\
\hline Range of days & $01-13$ & $14-17$ & $18-21$ & $22-26$ & $27-02$ & 03-09 & $10-18$ & $19-26$ & $27-01$ & $02-06$ & $07-10$ \\
\hline Average temp. $\left({ }^{\circ} \mathrm{C}\right)$ & 12.7 & 12.8 & 16.0 & 15.1 & 11.5 & 13.3 & 15.2 & 16.1 & 20.1 & 20.4 & 17.6 \\
\hline Sum of precipitation $(\mathrm{mm})$ & 18.5 & 0.5 & 15.4 & 4.2 & 61.0 & 4.1 & 16.4 & 90.3 & 0.0 & 14.0 & 14.3 \\
\hline \multirow[t]{2}{*}{2010} & \multicolumn{4}{|l|}{ May } & \multicolumn{5}{|l|}{ June } & \multicolumn{2}{|l|}{ July } \\
\hline & 11 & 22 & 26 & 29 & 06 & 10 & 15 & 23 & 29 & 07 & 10 \\
\hline Polar & $\mathrm{L}$ & $\mathrm{L}$ & $\mathrm{L} / \mathrm{I}$ & $\mathrm{I} / \mathrm{F}$ & $\mathrm{F}^{*}$ & $\mathrm{~F} / \mathrm{P}$ & $\mathrm{P}$ & $\mathrm{P}$ & & & \\
\hline Izolda & $\mathrm{L}$ & $\mathrm{L}$ & $\mathrm{L}$ & $\mathrm{L} / \mathrm{I}$ & $\mathrm{I} / \mathrm{F}$ & $\mathrm{F}^{*}$ & $\mathrm{~F} / \mathrm{P}$ & $\mathrm{P}$ & $\mathrm{P}$ & $\mathrm{P}$ & \\
\hline Tarchalska & $\mathrm{L}$ & $\mathrm{L}$ & $\mathrm{L}$ & $\mathrm{L}$ & $\mathrm{L} / \mathrm{I}$ & $\mathrm{I} / \mathrm{F}$ & $\mathrm{F}^{*}$ & $\mathrm{~F} / \mathrm{P}$ & $\mathrm{P}$ & $\mathrm{P}$ & $\mathrm{P}$ \\
\hline Range of days & $01-11$ & $12-20$ & $23-26$ & $27-29$ & $30-06$ & $07-10$ & $11-15$ & $16-23$ & $24-29$ & $30-07$ & $08-10$ \\
\hline Average temp. $\left({ }^{\circ} \mathrm{C}\right)$ & 12.9 & 10.4 & 14.5 & 15.0 & 15.7 & 22.4 & 19.9 & 15.7 & 17.0 & 20.1 & 19.4 \\
\hline Sum of precipitation $(\mathrm{mm})$ & 82.5 & 184.0 & 15.9 & 0.0 & 100.9 & 0.0 & 16.0 & 30.8 & 4.0 & 27.8 & 0.0 \\
\hline
\end{tabular}

$L$ development of main shoot and leaves (BBCH 35-39), $I$ inflorescence emergence (BBCH 50-59), $F$ flowering (BBCH 60-69), $P$ development of pods (BBCH 70-75)

*Full flowering: $50 \%$ of open flowers

Fig. 1 Spectral reflectance of coloured sticky traps

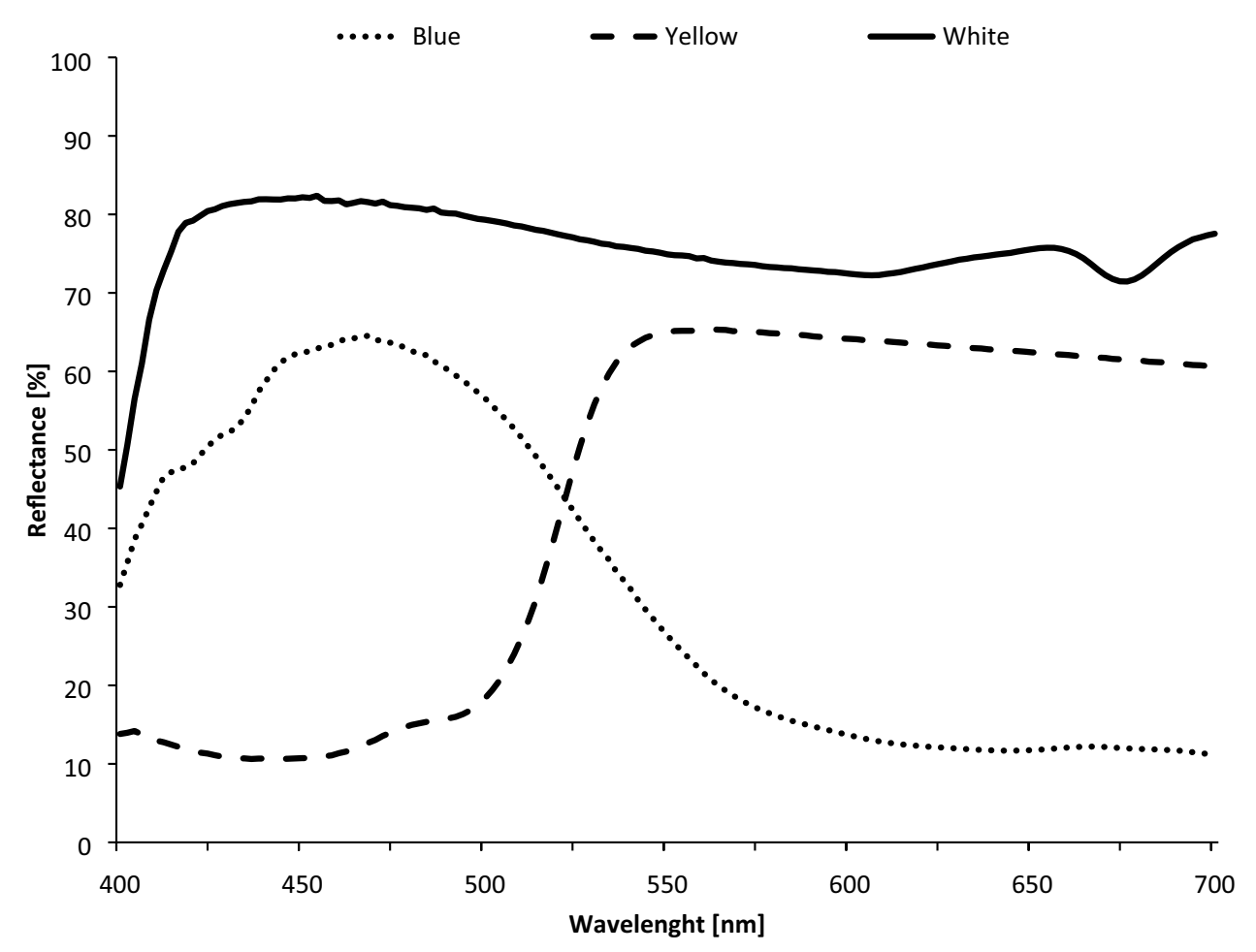

consisted of 25 sweeps within each plot and was stored in a plastic bag. The samples from the plants were obtained at the same time when the traps were collected from the pea plots. Adult thrips collected from plants were extracted and kept in a conservation fluid (60\% alcohol with glycerol) until examination in the laboratory. 


\section{Thrips identification}

After the traps were transferred to the laboratory, each of the coloured traps was examined, and all thrips collected were counted using a stereoscopic microscope. Specimens of A. intermedius were separated from other species under a binocular microscope. To determine the harmful thrips species, it was necessary to remove them from the sticky traps (using mineral spirits) so that $F$. intonsa, T. fuscipennis and T. tabaci could be separated using a stereoscopic microscope with light transmission. Subsequently, the thrips (when necessary) were placed on microscope slides in Heinz solution and identified to species level under a compound microscope. Adult thrips collected from plants were mounted on microscope slides in accordance with the methodology proposed by Zawirska (1994) and identified to species level according to Zawirska (1994) and Strassenzur (2003).

\section{Statistical analysis}

Each thrips species was separately analysed for each year using two-way analysis of variance (ANOVA), with trap colour and pea cultivar as the main effects. Additionally, one-way ANOVA was performed to investigate the differences among cultivars with respect to thrips infestation. Data were normalised using $\log _{10}(x+1)$ transformation, and the residual plots of the transformed data were examined to ensure that the data were normally distributed. Comparisons of the mean numbers of thrips obtained in trap sampling and from plants were made using Duncan's multiple range test $(P<0.05)$. Tables and figures show untransformed means. To determine the relationship between the number of thrips caught on the traps and those obtained from plants, Pearson's linear correlation coefficient $(r)$ was calculated for $\log _{10}(x+1)$-transformed data, and its significance was estimated at $P<0.05$. All statistical analyses were performed using the software PASW Statistics 13.0 by SPSS Inc.

\section{Results}

\section{Trap colour and cultivar preference}

In the field experiment, the number of captured thrips specimens was significantly affected by trap colour, pea cultivar and interaction between these factors (Table 2). The two most attractive trap base colours for thrips were blue and yellow. The blue trap differed considerably from the yellow one by having a moderately high reflectance in the violet region and a prominent peak in the blue region $(450 \mathrm{~nm})$, while the yellow traps had a peak at $550 \mathrm{~nm}$ (green region) and high reflectance in the yellow, orange
Table 2 ANOVA results showing the effects of cultivar and trap colour on the number of adult specimens of Frankliniella intonsa, Thrips fuscipennis, Thrips tabaci and Aeolothrips intermedius in the seasons 2009-2010

\begin{tabular}{|c|c|c|c|c|c|}
\hline \multirow[t]{3}{*}{ Source } & \multirow[t]{3}{*}{$d f$} & \multicolumn{4}{|l|}{ Year } \\
\hline & & \multicolumn{2}{|l|}{2009} & \multicolumn{2}{|l|}{2010} \\
\hline & & $F$ & $p$ & $F$ & $p$ \\
\hline \multicolumn{6}{|c|}{ Frankliniella intonsa } \\
\hline Cultivar & 2 & 4.642 & $0.018^{*}$ & 1.327 & 0.282 \\
\hline Trap colour & 2 & 196.616 & $0.000 * *$ & 218.637 & $0.000 * *$ \\
\hline Interaction & 4 & 3.248 & $0.027 *$ & 2.950 & $0.038^{*}$ \\
\hline \multicolumn{6}{|c|}{ Thrips fuscipennis } \\
\hline Cultivar & 2 & 6.089 & $0.007 * *$ & 26.303 & $0.000 * *$ \\
\hline Trap colour & 2 & 141.937 & $0.000 * *$ & 205.543 & $0.000^{* *}$ \\
\hline Interaction & 4 & 5.304 & $0.003 * *$ & 6.831 & $0.000 * *$ \\
\hline \multicolumn{6}{|l|}{ Thrips tabaci } \\
\hline Cultivar & 2 & 36.889 & $0.000 * *$ & 13.045 & $0.000 * *$ \\
\hline Trap colour & 2 & 60.525 & $0.000 * *$ & 129.990 & $0.000 * *$ \\
\hline Interaction & 4 & 4.304 & $0.008 * *$ & 0.229 & 0.919 \\
\hline \multicolumn{6}{|c|}{ Aeolothrips intermedius } \\
\hline Cultivar & 2 & 24.010 & $0.000 * *$ & 5.916 & $0.007 * *$ \\
\hline Trap colour & 2 & 43.757 & $0.000 * *$ & 98.307 & $0.000^{* * *}$ \\
\hline Interaction & 4 & 2.444 & 0.070 & 1.879 & 0.143 \\
\hline
\end{tabular}

*Significant at $P<0.05 ; * *$ significant at $P<0.01$

and red spectral regions (from 550 to $700 \mathrm{~nm}$ ). White traps had increasing reflectance in the violet region and were broadly reflective across the visible spectrum (Fig. 1). The species most caught on the blue traps were T. fuscipennis and T. tabaci. Irrespective of the pea cultivar, the mean number of these thrips species caught on the blue traps was significantly higher than that on the yellow and white traps in both years. The highest numbers of $F$. intonsa were captured on the blue and yellow traps; however, significantly more thrips were captured on yellow traps in 2010. In the case of $A$. intermedius, the yellow traps were significantly the most attractive. In both years, the white traps were significantly less attractive to all tested thrips species (Table 3 ). The cultivar effect was the strongest in the case of T. tabaci in $2009(F=36.889, P<0.000)$ and T. fuscipennis in $2010(F=26.303, P<0.000)$. In the case of $F$. intonsa, significant cultivar effect was found only in 2009 ( $P<4.642)$ (Table 2). More thrips were caught on the traps located in the plots with cultivars characterised by a longer growing season, which were inhabited by large numbers of thrips, namely of the cultivars Tarchalska or Izolda (Tables 3, 4). In 2009, most $F$. intonsa were captured on the blue traps located in the plots with cv. Izolda and Tarchalska and on the yellow traps in the plots with $\mathrm{cv}$. Polar, while in 2010, the opposite patter was observed. In 
Table 3 Number of adult specimens of Frankliniella intonsa, Thrips fuscipennis, Thrips tabaci and Aeolothrips intermedius caught in pea cultivars 'Polar', 'Izolda' and 'Tarchalska' with blue, yellow and white sticky traps in the seasons 2009-2010

\begin{tabular}{|c|c|c|c|c|c|c|c|c|}
\hline \multirow{4}{*}{$\begin{array}{l}\text { Year } \\
\text { Thrips species }\end{array}$} & \multicolumn{8}{|c|}{ Mean \pm SE number of adult specimens } \\
\hline & 2009 & 2010 & & & & & & \\
\hline & \multicolumn{8}{|c|}{ Frankliniella intonsa } \\
\hline & & \multicolumn{7}{|c|}{ Trap colour } \\
\hline Cultivar & Blue & Yellow & White & Mean & Blue & Yellow & White & Mean \\
\hline Polar & $31.0 \pm 1.8 \mathrm{~B}^{\mathrm{y}}$ & $34.1 \pm 1.3 \mathrm{AB}$ & $14.6 \pm 2.2 \mathrm{C}$ & $25.1 \pm 2.8 b^{x}$ & $17.2 \pm 0.5 \mathrm{~B}$ & $16.2 \pm 0.2 \mathrm{~B}$ & $6.4 \pm 0.7 \mathrm{C}$ & $13.3 \pm 1.5^{\#}$ \\
\hline Izolda & $34.6 \pm 1.9 \mathrm{AB}$ & $30.7 \pm 1.5 \mathrm{~B}$ & $9.8 \pm 0.5 \mathrm{D}$ & $25.0 \pm 3.5 \mathrm{~b}$ & $16.8 \pm 1.4 \mathrm{~B}$ & $18.9 \pm 0.9 \mathrm{~B}$ & $6.1 \pm 0.5 \mathrm{C}$ & $13.9 \pm 1.8$ \\
\hline Tarchalska & $41.4 \pm 1.2 \mathrm{~A}$ & $36.3 \pm 1.6 \mathrm{AB}$ & $12.2 \pm 1.4 \mathrm{CD}$ & $29.9 \pm 3.6 \mathrm{a}$ & $17.6 \pm 0.7 \mathrm{~B}$ & $24.3 \pm 2.8 \mathrm{~A}$ & $5.7 \pm 0.5 \mathrm{C}$ & $15.8 \pm 2.5$ \\
\hline Mean & $35.7 \pm 1.5 \mathrm{a}^{\mathrm{x}}$ & $33.7 \pm 1.0 \mathrm{a}$ & $12.2 \pm 1.0 \mathrm{~b}$ & & $17.2 \pm 0.6 \mathrm{~b}$ & $19.8 \pm 1.4 \mathrm{a}$ & $6.0 \pm 0.3 \mathrm{c}$ & \\
\hline Thrips species & \multicolumn{8}{|c|}{ Thrips fuscipennis } \\
\hline Polar & $22.6 \pm 0.9 \mathrm{~B}$ & $20.9 \pm 0.8 \mathrm{~B}$ & $13.6 \pm 0.6 \mathrm{C}$ & $19.1 \pm 1.2 \mathrm{~b}$ & $21.4 \pm 1.5 \mathrm{BC}$ & $11.2 \pm 1.1 \mathrm{D}$ & $3.2 \pm 0.7 \mathrm{~F}$ & $11.9 \pm 2.3 \mathrm{c}$ \\
\hline Izolda & $33.9 \pm 0.5 \mathrm{~A}$ & $22.2 \pm 0.4 \mathrm{~B}$ & $13.8 \pm 0.6 \mathrm{C}$ & $23.3 \pm 2.5 \mathrm{a}$ & $33.5 \pm 1.5 \mathrm{~A}$ & $21.9 \pm 1.7 \mathrm{BC}$ & $6.25 \pm 0.5 \mathrm{E}$ & $20.5 \pm 3.4 \mathrm{a}$ \\
\hline Tarchalska & $32.3 \pm 3.9 \mathrm{~A}$ & $24.2 \pm 2.0 \mathrm{~B}$ & $12.3 \pm 0.9 \mathrm{C}$ & $22.9 \pm 2.8 \mathrm{a}$ & $17.0 \pm 0.9 \mathrm{C}$ & $24.3 \pm 1.8 \mathrm{~B}$ & $5.14 \pm 0.6 \mathrm{E}$ & $15.4 \pm 2.4 b$ \\
\hline Mean & $29.6 \pm 1.9 \mathrm{a}$ & $22.5 \pm 0.8 b$ & $13.2 \pm 0.4 \mathrm{c}$ & & $23.9 \pm 2.2 \mathrm{a}$ & $19.1 \pm 1.9 \mathrm{~b}$ & $4.9 \pm 0.5 \mathrm{c}$ & \\
\hline Thrips species & \multicolumn{8}{|l|}{ Thrips tabaci } \\
\hline Polar & $8.1 \pm 1.9 \mathrm{~B}$ & $5.4 \pm 0.8 \mathrm{C}$ & $2.9 \pm 0.9 \mathrm{D}$ & $5.5 \pm 0.7 \mathrm{c}$ & $7.3 \pm 1.8$ & $5.5 \pm 1.1$ & $1.7 \pm 0.8$ & $4.8 \pm 0.8 \mathrm{c}$ \\
\hline Izolda & $9.9 \pm 0.9 \mathrm{AB}$ & $7.5 \pm 0.8 \mathrm{~B}$ & $3.6 \pm 0.9 \mathrm{D}$ & $7.0 \pm 0.8 b$ & $13.6 \pm 2.8$ & $8.8 \pm 1.6$ & $2.7 \pm 0.8$ & $8.3 \pm 1.4 \mathrm{a}$ \\
\hline Tarchalska & $12.0 \pm 1.6 \mathrm{~A}$ & $9.3 \pm 0.9 \mathrm{AB}$ & $7.8 \pm 0.5 \mathrm{~B}$ & $9.7 \pm 0.6 \mathrm{a}$ & $10.6 \pm 1.4$ & $6.4 \pm 0.6$ & $1.9 \pm 0.3$ & $6.3 \pm 1.1 \mathrm{~b}$ \\
\hline Mean & $10.0 \pm 0.6 \mathrm{a}$ & $7.4 \pm 0.5 b$ & $4.7 \pm 0.7 \mathrm{c}$ & & $10.5 \pm 0.9 \mathrm{a}$ & $6.9 \pm 0.5 b$ & $2.1 \pm 0.2 \mathrm{c}$ & \\
\hline Thrips species & \multicolumn{8}{|c|}{ Aeolothrips intermedius } \\
\hline Polar & $6.9 \pm 1.2^{\#}$ & $9.5 \pm 0.8$ & $5.4 \pm 0.8$ & $7.3 \pm 0.6 \mathrm{a}$ & $3.1 \pm 0.8$ & $4.9 \pm 0.7$ & $1.1 \pm 0.5$ & $3.1 \pm 0.5 b$ \\
\hline Izolda & $5.3 \pm 0.9$ & $6.2 \pm 0.4$ & $4.7 \pm 0.6$ & $5.4 \pm 0.3 b$ & $3.5 \pm 0.2$ & $5.5 \pm 0.8$ & $1.5 \pm 0.5$ & $3.5 \pm 0.5 \mathrm{ab}$ \\
\hline Tarchalska & $8.1 \pm 0.8$ & $9.3 \pm 0.3$ & $5.4 \pm 0.8$ & $7.6 \pm 0.5 \mathrm{a}$ & $6.1 \pm 1.2$ & $6.1 \pm 1.0$ & $1.3 \pm 0.3$ & $4.5 \pm 0.7 \mathrm{a}$ \\
\hline Mean & $6.8 \pm 0.4 b$ & $8.4 \pm 0.5 \mathrm{a}$ & $5.1 \pm 0.2 \mathrm{c}$ & & $4.3 \pm 0.5 b$ & $5.5 \pm 0.3 \mathrm{a}$ & $1.3 \pm 0.1 \mathrm{c}$ & \\
\hline
\end{tabular}

${ }^{\mathrm{x}}$ Means in rows (cultivar) and columns (trap colour) marked with different letters are significantly different from each other (multiple Duncan's test $P<0.05$ )

${ }^{\mathrm{y}}$ Means marked with different capital letters in rows and columns (cultivar $\times$ trap colour interaction) are significantly different from each other (multiple Duncan's test $P<0.05$ )

${ }^{\#}$ Means without any letter were not compared (source of variation was not significant)

2010, a significantly lower number of thrips were collected on the blue traps in the plots with cv. Tarchalska (Table 3). In terms of individual numbers caught on sticky traps, $T$. fuscipennis was second. A significantly higher number of thrips was collected from blue traps located in the plots with the cultivars Izolda and Tarchalska in 2009 and Polar and Izolda in 2010 (Table 3); a similar relationship was found in the case of $T$. tabaci. The mean number of $T$. tabaci specimens captured on the blue traps was greater than that on the yellow traps, the second most preferred colour by thrips. A significantly higher number of onion thrips was collected from blue traps located in the plots with cultivar Tarchalska in 2009 (Table 3). The mean number of the predatory A. intermedius caught on the yellow traps was higher than that on the blue and white traps in both years. There was no significant effect of interaction between trap colour and pea cultivar on the number of caught $T$. tabaci specimens in 2010 and A. intermedius specimens in both years (Tables 2, 3).

\section{Changes in thrips population densities on coloured sticky traps and on plants over time}

During both study years, the first thrips specimens were observed on the sticky traps when the pea plants were emerging, which was around the 10th of May (Figs. 2, 3, $4,5)$. Herbivorous thrips were usually detected on the traps a few days earlier or at the same time as on plants. In the initial period of pea plant colonisation by $F$. intonsa and $T$. Fuscipennis (1st and 2nd Dec. May), the number of flying thrips captured on the traps greatly exceeded the number of those collected from plants. Both thrips species were caught in similar numbers on the blue and yellow sticky traps, ranging from 0.7 to 12.2 thrips per one trap over one sampling period in 2009 and up to 14.7 thrips/trap in 2010. In turn, the colonisation of plants by $F$. intons $a$ and $T$. fuscipennis in the initial period did not exceed 1.5 specimens/plot on average (Figs. 2, 3). The species T. tabaci was less attracted by the sticky traps, despite its larger population on plants. 
Table 4 Source of variation and the number of adult specimens of Frankliniella intonsa, Thrips fuscipennis, Thrips tabaci and Aeolothrips intermedius captured with an entomological sweep net from plants of pea cultivars 'Polar', 'Izolda' and 'Tarchalska' in the seasons 2009-2010 (one-way ANOVA)

\begin{tabular}{|c|c|c|c|c|c|c|c|}
\hline \multirow{3}{*}{$\begin{array}{l}\text { Year } \\
\text { Source: cultivar }\end{array}$} & \multirow[b]{3}{*}{$d f$} & \multicolumn{6}{|c|}{ Mean \pm SE number of adult specimens } \\
\hline & & \multicolumn{3}{|l|}{2009} & \multicolumn{3}{|l|}{2010} \\
\hline & & Mean & $F$ & $p$ & Mean & $F$ & $p$ \\
\hline \multicolumn{8}{|c|}{ Frankliniella intonsa } \\
\hline Polar & 2 & $3.3 \pm 0.2 \mathrm{c}^{\mathrm{x}}$ & 38.370 & $0.000 * *$ & $3.4 \pm 0.3 b$ & 7.482 & $0.012 * *$ \\
\hline Izolda & & $8.1 \pm 0.6 \mathrm{a}$ & & & $4.8 \pm 0.1 \mathrm{a}$ & & \\
\hline Tarchalska & & $4.3 \pm 0.4 \mathrm{~b}$ & & & $4.7 \pm 0.3 \mathrm{a}$ & & \\
\hline \multicolumn{8}{|c|}{ Thrips fuscipennis } \\
\hline Polar & 2 & $5.2 \pm 0.5 b$ & 18.388 & $0.000 * *$ & $3.1 \pm 0.4 \mathrm{c}$ & 37.259 & $0.000 * *$ \\
\hline Izolda & & $14.5 \pm 2.1 \mathrm{a}$ & & & $13.4 \pm 1.1 \mathrm{a}$ & & \\
\hline Tarchalska & & $7.3 \pm 0.6 b$ & & & $7.8 \pm 0.8 b$ & & \\
\hline \multicolumn{8}{|l|}{ Thrips tabaci } \\
\hline Polar & 2 & $3.2 \pm 0.3 \mathrm{c}$ & 13.948 & $0.002 * *$ & $2.6 \pm 0.3 \mathrm{a}$ & 3.598 & 0.071 \\
\hline Izolda & & $4.2 \pm 0.2 b$ & & & $3.5 \pm 0.3 \mathrm{a}$ & & \\
\hline Tarchalska & & $6.0 \pm 0.5 \mathrm{a}$ & & & $3.3 \pm 0.1 \mathrm{a}$ & & \\
\hline \multicolumn{8}{|c|}{ Aeolothrips intermedius } \\
\hline Polar & 2 & $0.6 \pm 0.1 \mathrm{c}$ & 62.783 & $0.000 * *$ & $1.8 \pm 0.2 \mathrm{a}$ & 2.478 & 0.139 \\
\hline Izolda & & $1.2 \pm 0.1 \mathrm{~b}$ & & & $2.1 \pm 0.1 \mathrm{a}$ & & \\
\hline Tarchalska & & $2.7 \pm 0.2 \mathrm{a}$ & & & $1.3 \pm 0.4 \mathrm{a}$ & & \\
\hline
\end{tabular}

${ }^{\mathrm{x}}$ Means in columns marked with different letters are significantly different from each other (multiple Duncan's test $P<0.05$ )

*Significant at $P<0.05 ; * *$ significant at $P<0.01$
In 2009, in the initial period of plant colonisation, when the average number of onion thrips on plants, depending on the cultivar, did not exceed 6.2 individuals/plot, the mean number of thrips captured on the traps ranged from 0.5 to 4.0 on the blue, from 0.0 to 3.2 on the yellow and up to 1.7 on the white traps. In 2010, a similar or slightly greater number of thrips were caught on the blue traps (from 0.75 to 2.25 thrips/trap) compared with those collected from plants (1.0 to 1.75 thrips/plot), while fewer were captured on the yellow ( 0.0 to 1.0 thrips/trap) and white traps ( 0.0 to 0.75 thrips/ trap) (Fig. 4). In both years, the number of captured flying thrips considerably increased in the pre-blooming, i.e. bud formation, period (BBCH 50-59), and the majority of the species was strongly associated with flowers, i.e. F. intonsa and T. fuscipennis were captured on the traps in the blooming period (BBCH 60-69) (from 20th of May to mid-June) (Figs. 2, 3). At that time, the average number of adult thrips captured on the blue traps was usually higher than that on the yellow ones and from 3 to 5.5 times greater than the average number recovered from plants. Following this period (BBCH 70-75), the populations of flower and rose thrips on plants declined rapidly, and thrips were already abandoning the cultivars which ended flowering. Subsequently, gradually decreasing numbers of flower and rose thrips were caught on the traps, although in some cases, a massive accumulation of thrips on the traps was observed at the end of the growing season (Figs. 2, 3). The numbers of T. tabaci peaked at flowering time and then, after a temporary decline, increased on plants again during pod development (Fig. 4). In general, the larger numbers of $T$. tabaci on flowers and pea pods corresponded to the greater numbers of this species on the sticky traps. During the population peak of onion thrips, the blue traps always caught more adults than the yellow ones, catching from 2 to 6 (in 2009) and to 7.7 (in 2010) times more when compared to the thrips collected from plants. The number of T. tabaci adults on coloured traps and plants decreased from the end of June, which coincided with the end of pod development (Table 1, Fig. 4). The population density of $A$. intermedius on the cultivars Polar and Izolda remained steady throughout the growing season. Only in cv. Tarchalska, thrips numbers increased steadily from midMay in 2009 (BBCH 37-39) and from the beginning of June (BBCH 50-59) in 2010. Yellow was the most attractive colour, followed by blue and white. The time of catching the largest number of $A$. intermedius on all tested coloured traps was not correlated with the period of their most abundant occurrence on plants (sometimes separated by up to 3 to 4 weeks) and was not correlated with a particular stage of pea development (Table 1; Fig. 5). When leaving the pea plots, larger numbers of flying $A$. intermedius accumulated mainly on the yellow traps (Fig. 5).

Comparison of traps with plants within all sampling periods indicates a significantly high positive correlation for $F$. intonsa in both years and for all tested colour traps ( $r=0.483-0.795)$ (Table 5). Also, for T. tabaci caught almost on all tested colour traps, a significantly positive correlation 

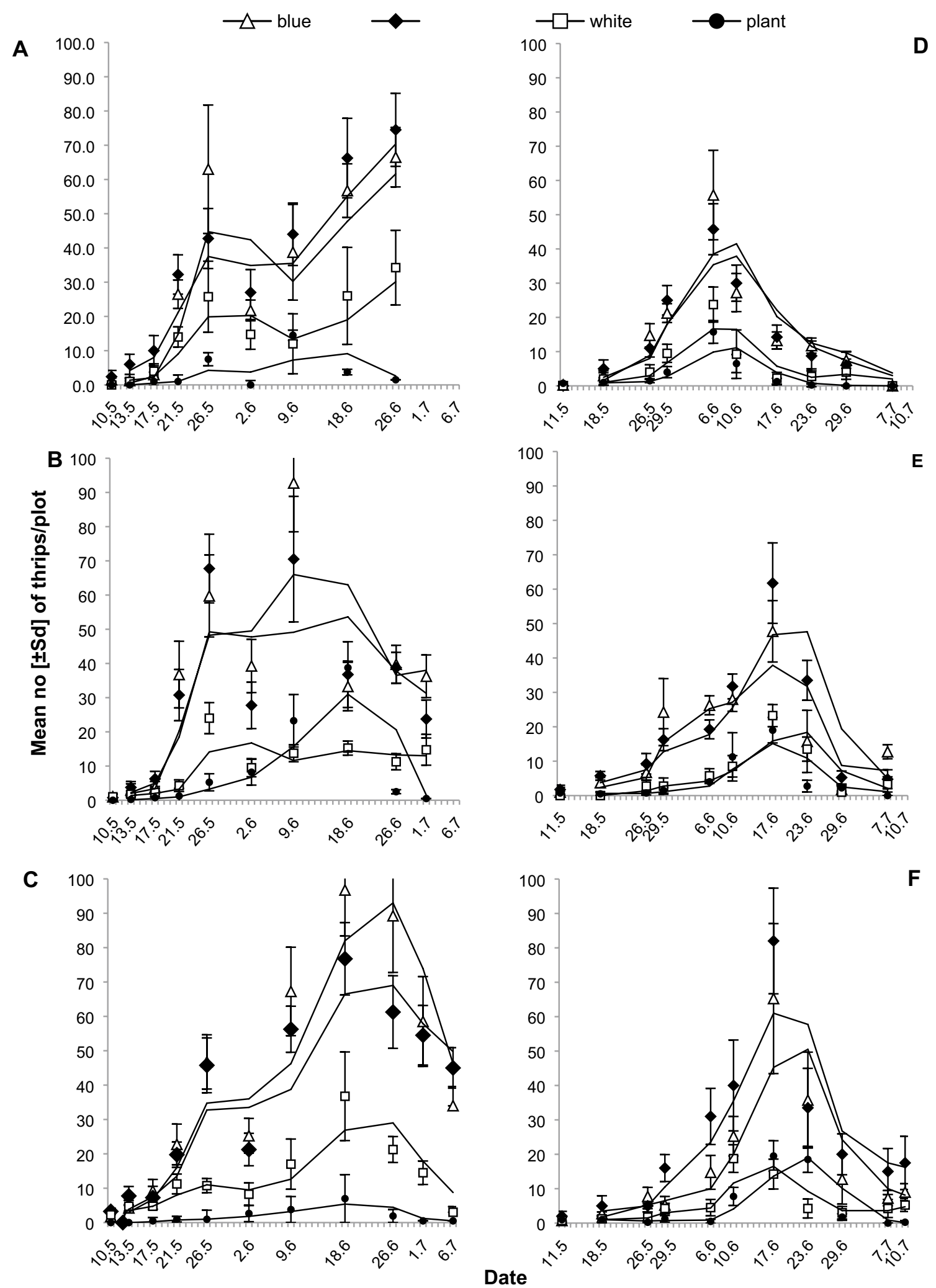

Fig. 2 Seasonal fluctuations in the number of adult Frankliniella intonsa caught in the three pea cultivars Polar (a, d), Izolda (b, e) and Tarchalska $(\mathbf{c}, \mathbf{f})$ with blue, yellow and white sticky traps and in the number of those caught from plants with a sweep net in 2009 (a-c) and $2010(\mathbf{d}-\mathbf{f})$ 

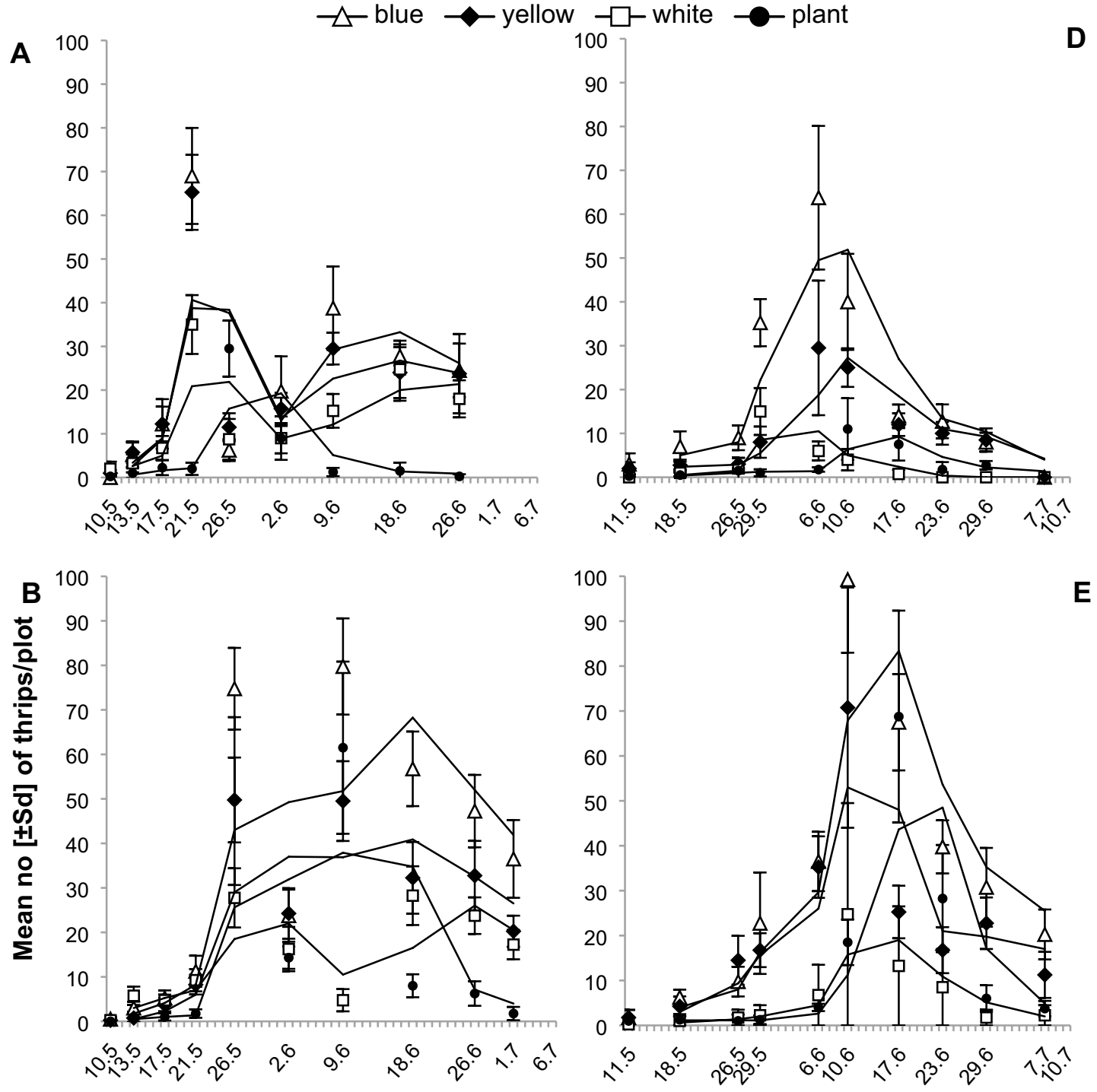

C

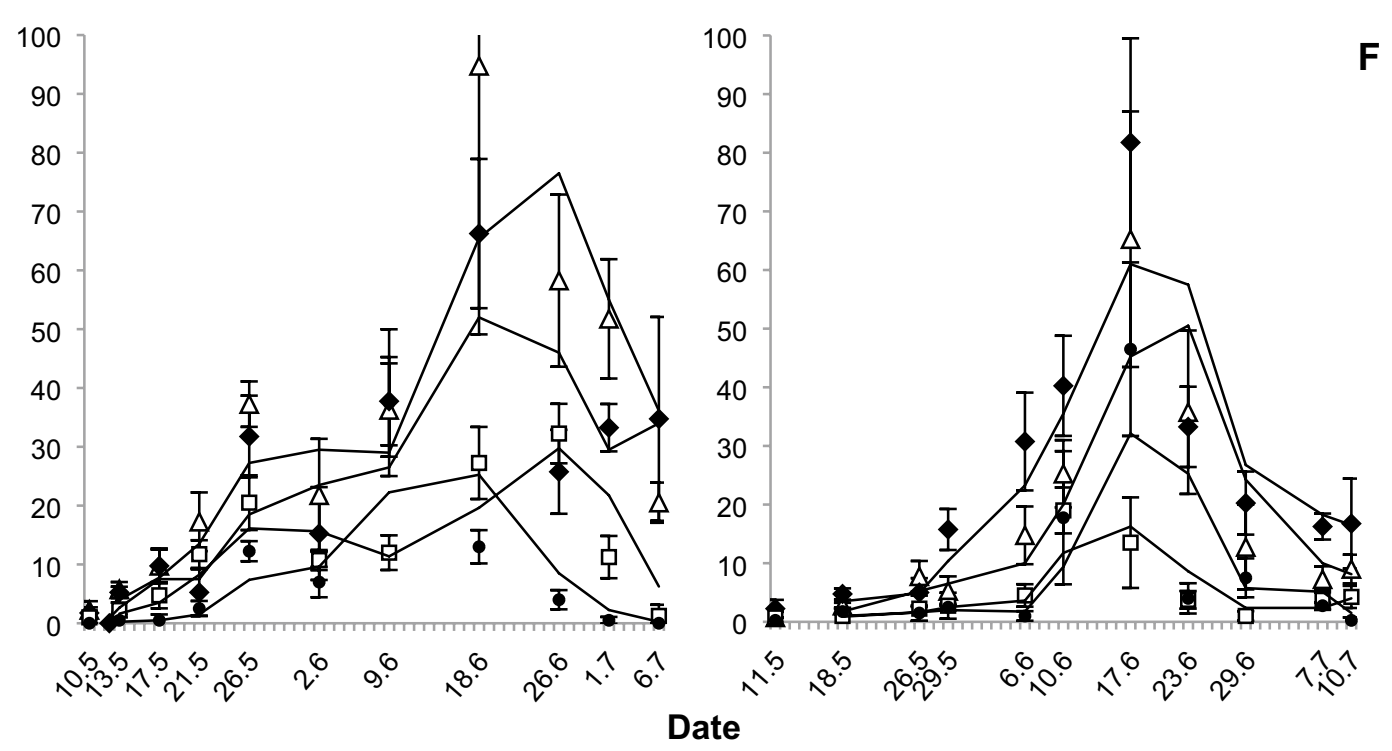


4Fig. 3 Seasonal fluctuations in the number of adult Thrips fuscipennis caught in the three pea cultivars Polar (a, d), Izolda (b, e) and Tarchalska (c, f) with blue, yellow and white sticky traps and in the number of those caught from plants with a sweep net in 2009 (a-c) and $2010(\mathbf{d}-\mathbf{f})$

was found; however, the strongest relationships were mainly in relation to the blue traps located in the plots with the cultivars Polar and Izolda ( $r=0.663-0.773)$. For T. fuscipennis, a high significantly positive relationship $(r>0.506)$ between the numbers of thrips caught on blue and yellow traps was noticed only in 2009 (Table 5). In the case of the predatory A. intermedius, a significant correlation was found mostly in relation to the blue and yellow traps (Table 5).

Population densities of all thrips species on the traps and on plants depended on air temperature and rainfall and were lower in the rainy period. In 2010, the month of May and the first days of June were particularly rainy, with downpours from May 15 to 17, and during the entire month, there were only 5 days without rain (Table 1 ).

\section{Discussion}

The weekly catches of thrips on the coloured traps relative to the measured adult populations on plants indicate that the size of herbivorous thrips populations changes over the season, depending on host plant phenology. The fluctuations in the populations of thrips on pea plants were similar for all cultivars in both experimental years, but thrips abundance was lower in 2010. This may have been caused by the rainy period and the lower daily average temperature in May 2010, negatively affecting the seasonal occurrence and population densities of adult thrips. The late entry into the flowering and pod ripening periods of the medium-early $\mathrm{cv}$. Izolda and the medium-late cv. Tarchalska promoted thrips population growth in pea and increased their numbers on sticky traps. The most frequently collected species from pea plants were $F$. intonsa and $T$. fuscipennis. They are generally not considered as a pest of pea plants; however, their high abundance on pea plants, particularly around bloom time, indicates that these species can cause an economic loss. The damaging of flowers by $F$. intonsa and T. fuscipennis through feeding and oviposition negatively affects pea pod development and potentially results in premature flower drop (Pobozniak 2013). There were significant differences between collection dates, with the largest collections of flower and rose thrips during the bloom period and moderate collections after bloom; few thrips were collected in pre-bloom. In some cases, their reconnaissance flights increased when the flowers were scarce because they feed on pollen and were probably looking for food. In earlier studies, yellow-coloured traps were suggested (Cho et al. 1995; Lim and Mainali 2009) as suitable for monitoring $F$. intonsa. In the detailed experiments by Seo et al. (2006), blue colour proved to be most attractive to flower thrips. In contrast to their findings, the results of our current study indicate that both blue and yellow traps captured $F$. intonsa to a similar extent, while T. fuscipennis was most attracted to blue sticky traps. However, the difference between the blue and yellow colours was not significant, irrespective of the sampling period. The lack (in many cases) of a significant correlation between T. fuscipennis caught on plants and those caught on traps might be the result of flying thrips from adjacent pea plots being attracted to some of the coloured traps, thus dispersing individuals so that they did not land on the nearby plants. This would have reduced the populations on plants and inflated some trap catches.

The colour preference shown by different Frankliniella species has been investigated in several studies for different crops. Blue-coloured traps hold the strongest attraction for $F$. occidentalis (Allsopp 2010; Broughton and Harrison 2012; Chu et al. 2000), white-coloured ones for F. bispinosa (Childers and Brecht 1996) and for F. schultzei (Mueva et al. 2014) and yellow (Blumthal et al. 2005) and neon yellow traps for F. occidentalis (Demirel and Cranshaw 2005; Rőth et al. 2016). According to some authors, there are flowerinfesting species of thrips, e.g. T. imaginis and T. obscuratus (Teulon and Penman 2012), which are most attracted to traps whose colour corresponds to the colour of the flowers of their host plant. We found, however, that white traps did not attract $F$. intonsa and $T$. fuscipennis, despite the flowers of the host pea plants having an off-white colour. The white colour was also unattractive to the florivorous Frankliniella bispinosa in an olive grove (Allan and Gillet-Kaufman 2018). In contrast to the two flower-feeding taxa mentioned above, the disparities in the number of $T$. tabaci during different phenological phases of pea were not as large, and the onion thrips were present in all plant samples, regardless of the development stage of pea development. In the initial period of onion thrips settlement, the blue traps always caught more adults than the yellow and white traps at an earlier time and in consistently higher numbers when compared to the numbers of thrips found on plants, indicating that blue traps are the most sensitive ones and could function as an early warning of onion thrips activity.

As the population of T. tabaci on plants increased, the number of adults on the traps also increased, and a similar order in the effectiveness of traps in capturing thrips was seen, with blue traps generally being the most effective ones and white traps being the least effective ones. Comparison of thrips captures by trapping date indicates that both blue and yellow traps can predict an increase or decrease in the thrips population on plants, which can be helpful in determining the time of the most intense colonisation by onion thrips. In contrast to rose thrips, a similar analysis showed 
A

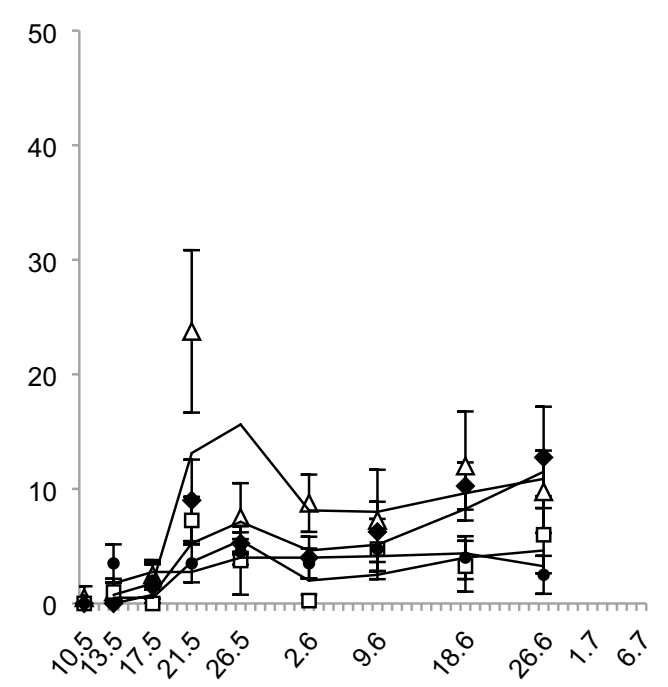

B
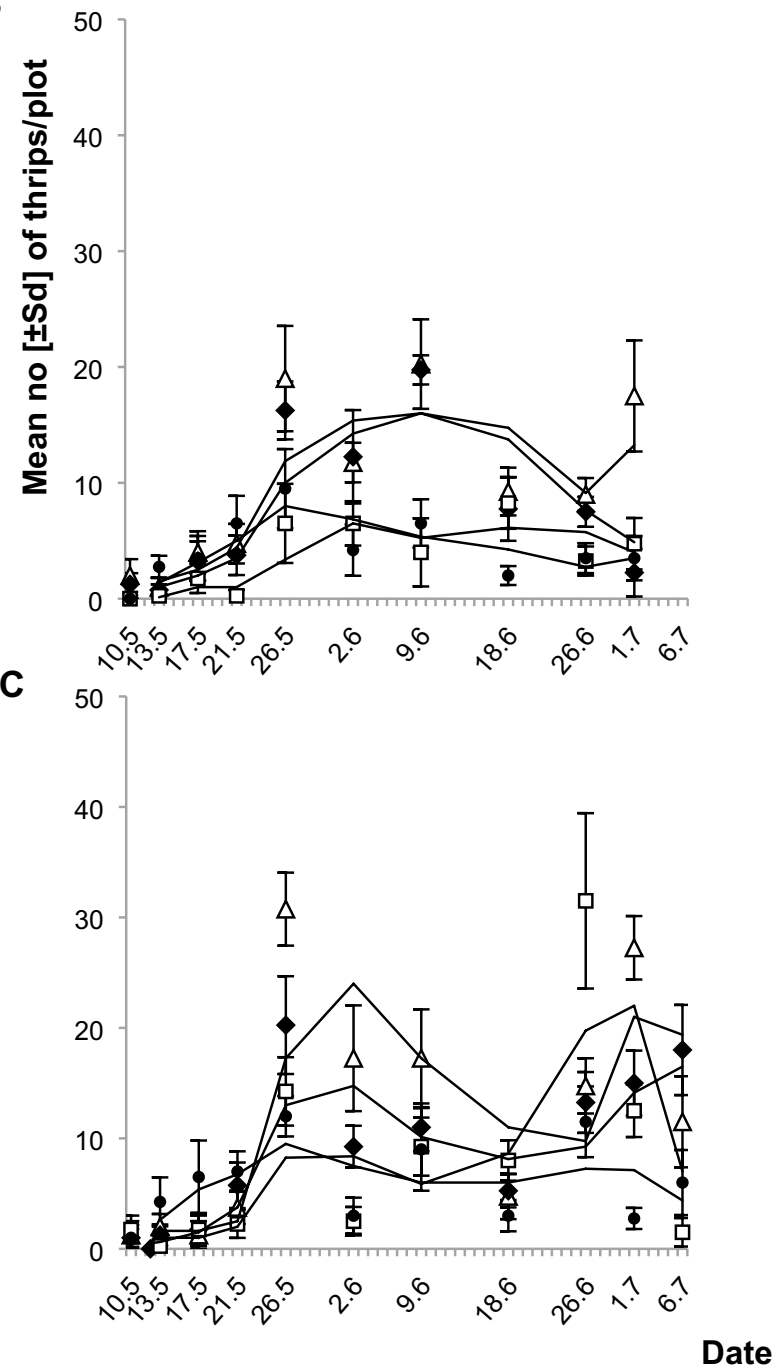

plant
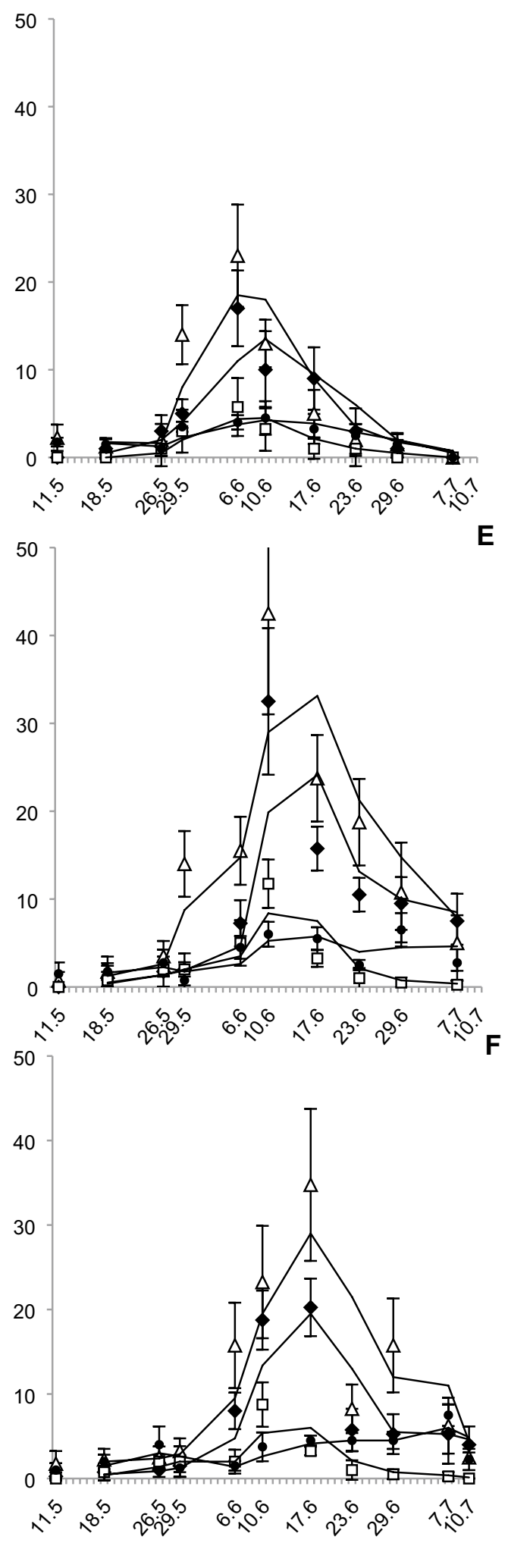

Fig. 4 Seasonal fluctuations in the number of adult Thrips tabaci caught in the three pea cultivars Polar (a, d), Izolda (b, e) and Tarchalska (c, f) with blue, yellow and white sticky traps and in the number of those caught from plants with a sweep net in 2009 (a-c) and 2010 (d-f) 

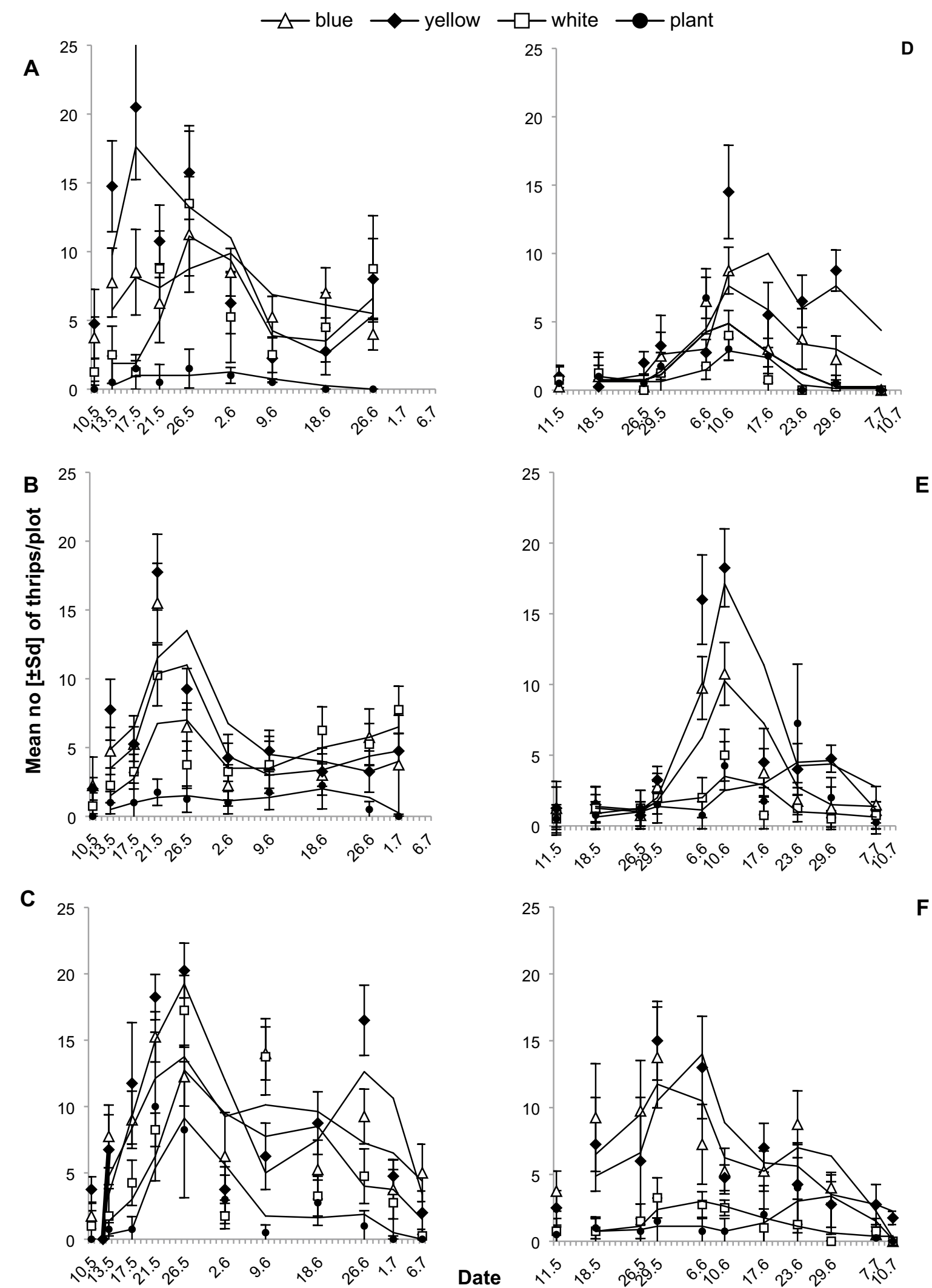

Fig. 5 Seasonal fluctuations in the number of adult Aeolothrips intermedius caught in the three pea cultivars Polar $(\mathbf{a}, \mathbf{d})$, Izolda $(\mathbf{b}, \mathbf{e})$ and Tarchalska (c, f) with blue, yellow and white sticky traps and in the

number of those caught from plants with a sweep net in 2009 (a-c) and $2010(\mathbf{d}-\mathbf{f})$ 
Table 5 Coefficients of correlation $(r)$ between the number of thrips caught on differently coloured sticky traps and the number of thrips collected from plants of pea cultivars 'Polar', 'Izolda' and 'Tarchalska' in the seasons 2009-2010, $N=44$

\begin{tabular}{|c|c|c|c|c|c|c|c|c|c|c|}
\hline \multirow[t]{2}{*}{ Cultivar } & \multirow[t]{2}{*}{ Trap colour } & \multirow[t]{2}{*}{ Year } & \multicolumn{2}{|c|}{$\begin{array}{l}\text { Frankliniella } \\
\text { intonsa }\end{array}$} & \multicolumn{2}{|c|}{$\begin{array}{l}\text { Thrips fuscipen- } \\
\text { nis }\end{array}$} & \multicolumn{2}{|c|}{ Thrips tabaci } & \multicolumn{2}{|c|}{$\begin{array}{l}\text { Aeolothrips inter- } \\
\text { medius }\end{array}$} \\
\hline & & & $r$ & $P$ & $r$ & $P$ & $r$ & $P$ & $r$ & $P$ \\
\hline \multirow[t]{6}{*}{ Polar } & \multirow[t]{2}{*}{ Blue } & 2009 & 0.532 & 0.000 & 0.534 & 0.000 & 0.773 & 0.000 & 0.349 & 0.020 \\
\hline & & 2010 & 0.721 & 0.000 & 0.170 & $0.270^{*}$ & 0.720 & 0.000 & 0.638 & 0.000 \\
\hline & \multirow[t]{2}{*}{ Yellow } & 2009 & 0.483 & 0.001 & 0.509 & 0.000 & 0.568 & 0.000 & 0.456 & 0.001 \\
\hline & & 2010 & 0.741 & 0.000 & 0.329 & 0.029 & 0.660 & 0.000 & 0.341 & 0.023 \\
\hline & \multirow[t]{2}{*}{ White } & 2009 & 0.487 & 0.001 & 0.522 & 0.000 & 0.589 & 0.000 & 0.264 & $0.084 *$ \\
\hline & & 2010 & 0.795 & 0.000 & -0.229 & $0.136^{*}$ & 0.603 & 0.000 & 0.616 & 0.014 \\
\hline \multirow[t]{6}{*}{ Izolda } & \multirow[t]{2}{*}{ Blue } & 2009 & 0.626 & 0.000 & 0.521 & 0.000 & 0.725 & 0.000 & 0.388 & 0.009 \\
\hline & & 2010 & 0.658 & 0.000 & 0.218 & $0.154^{*}$ & 0.663 & 0.000 & 0.353 & 0.019 \\
\hline & \multirow[t]{2}{*}{ Yellow } & 2009 & 0.608 & 0.000 & 0.506 & 0.000 & 0.686 & 0.000 & 0.416 & 0.005 \\
\hline & & 2010 & 0.771 & 0.000 & 0.123 & $0.427 *$ & 0.693 & 0.000 & 0.439 & 0.003 \\
\hline & \multirow[t]{2}{*}{ White } & 2009 & 0.481 & 0.001 & 0.317 & 0.036 & 0.458 & 0.002 & 0.354 & 0.018 \\
\hline & & 2010 & 0.721 & 0.000 & -0.017 & $0.915^{*}$ & 0.466 & 0.001 & 0.204 & $0.185^{*}$ \\
\hline \multirow[t]{6}{*}{ Tarchalska } & \multirow[t]{2}{*}{ Blue } & 2009 & 0.548 & 0.000 & 0.649 & 0.000 & 0.471 & 0.001 & 0.515 & 0.000 \\
\hline & & 2010 & 0.680 & 0.000 & 0.267 & $0.079 *$ & 0.382 & 0.011 & 0.353 & 0.019 \\
\hline & \multirow[t]{2}{*}{ Yellow } & 2009 & 0.494 & 0.001 & 0.605 & 0.000 & 0.440 & 0.003 & 0.554 & 0.000 \\
\hline & & 2010 & 0.605 & 0.000 & 0.291 & $0.055^{*}$ & 0.444 & 0.003 & 0.028 & $0.855^{*}$ \\
\hline & \multirow[t]{2}{*}{ White } & 2009 & 0.548 & 0.000 & 0.649 & 0.000 & 0.471 & 0.001 & 0.515 & 0.000 \\
\hline & & 2010 & 0.499 & 0.001 & -0.060 & $0.699 *$ & 0.122 & $0.429 *$ & -0.097 & $0.532 *$ \\
\hline
\end{tabular}

*No significant at $P<0.05$ a significant positive correlation for adults of onion thrips on plants as well as for adults caught on blue, yellow and white traps in all cultivars. Most likely, this is because $T$. tabaci also feeds on young foliage, and after flowering, it remains in the pea crop and continues to feed on pea pods. Blue colour was also more attractive to T. tabaci than yellow in lettuce and onion plots (Natwick et al. 2007). In the detailed experiments by Brødsgaard (1989), blue colour proved to be the most attractive, but it seems that different shades of blue show differences in attractiveness. In contrast to our results and those mentioned above, Gharekhani et al. (2014) showed that yellow traps were more appropriate for monitoring onion thrips in garlic, onion and tomato crops. In turn, Jenser et al. (2001) reported that although yellow traps caught specimens of onion thrips in high numbers, a significant difference was not established in the attractiveness between yellow and blue traps in tobacco crops. Similar to our results, the authors mentioned above showed a low attractiveness of white traps to T. tabaci. Rőth et al. (2016), studying visual systems of $T$. tabaci based on captures with coloured traps, concluded that yellow and white traps were similarly attractive to onion thrips, while fluorescent yellow had the strongest and blue the weakest attraction. Many studies have shown that differences in the shade of the same colour and in the interaction between thrips and host plants may explain why a given species of thrips prefers a different colour in different experiments. For this reason, the experimental methodology should include not only the description of the trap colour, but also the identification and presentation of the reflectance spectrum. It is important to provide a detailed physical characterisation of the traps used by including their reflectance patterns, as many different shades of colours currently available, and those likely to be produced in the future, may have a different attractiveness to pest insects. Comparing the relative light reflectance of blue and yellow traps, we detected that blue traps had a high reflectance in the violet region, with a prominent peak in the blue region $(450 \mathrm{~nm})$, while yellow traps reflected more light in the 550-780 $\mathrm{nm}$ range. This agrees with the study by Natwick et al. (2007), who report that blue sticky cards, which were the most attractive to $T$. tabaci, reflected considerably more light in the 400-500 nm range. In turn, Rôth et al. (2016) found that intense reflectance in the greenish yellow region $(540-570 \mathrm{~nm})$ had attraction for $T$. tabaci, whereas the bluish green region of light, around $500 \mathrm{~nm}$, was attractive to $F$. occidentalis. In our study, high reflectance in the green region and high reflectance in the yellow region were shown by the yellow traps, which captured fewer thrips than the blue ones, but the numbers were relatively high. The contradictory results of our study might be explained by some factors exerting influence on colour preference by thrips. The appearance of a colour does not only depend on the reflected wavelength, but also on other physical characteristics such as shininess or smoothness of a given surface, as well as trap size, dispersal distance and direction of thrips movement (Moreno et al. 1984; Roth et al. 2016). Recent 
studies by Otieno et al. (2018) indicate that adding blue narrow bandwidth LEDs with a peak emission of $445 \mathrm{~nm}$ to the blue sticky traps enhanced their performance for trapping western flower thrips as compared to conventional blue sticky traps. Also, the effects of other stimuli (biochemical, physiological, etc.) may modify insect behaviour (Koschier et al. 2002; Otieno et al. 2018; Symporien et al. 2018). In a detailed study on the susceptibility of pea cultivars to infestation and feeding by T. tabaci, Pobozniak (2013) stated that thrips were affected by the higher contents of green pigments in the leaves of pea plants, and the cultivars with grassy or rich green-coloured leaves were the ones most frequently colonised by onion thrips. The positive phototaxis to the green part of the spectrum has also been observed in thrips by Diaz-Montano et al. (2012). There have, however, not yet been any physiological studies to provide information on the photoreceptor system of onion thrips, but, as suggested by some authors, the reflectance of the host plant plays an important role in the selection of a host plant by the insects (Bálint et al. 2013).

The numbers of $A$. intermedius, which is considered as predaceous, preying on thrips and aphids (Trdan et al. 2005a), were lower on white and blue traps than on yellow ones. The lack of a significant correlation (in some cases) between the numbers of thrips caught on white or yellow traps and the samples from plants can be explained by a high variation in flight density. Yellow is a broad-spectrum colour that attracts many insect species, including thrips. However, surprisingly, our results show that yellow traps were less effective in attracting herbivorous thrips (mainly the most harmful T. tabaci) than blue traps. Additionally, the use of yellow traps may be risky because they reduce the densities of the predaceous A. intermedius in pea fields, thus leading to an increase in pest numbers. Yellow traps also attract more Coccinella septempunctata (Maredia et al. 1992) and aphidophagous Syrphidae (Laubertie et al. 2006). Overall, among the tested trap colours, blue traps were the most effective ones in monitoring thrips in pea fields and could be used almost effortlessly, in contrast to the timeconsuming sampling of plants, for an early detection of the pest. We found that white traps were not very attractive to thrips. Based on our results, we recommend blue traps for monitoring thrips in pea fields, even though the behavioural mechanisms behind this preference in thrips are not clear. Consequently, the use of blue sticky traps can provide a more ecological control, taking into account the protection of predatory thrips and the sustainability of ecosystems.

Acknowledgements This study was supported by the N N310 142135 grant from the State Committee for Scientific Research in Poland. The authors would like to express their gratitude to Dr. Tomasz Wójtowicz from the University of Agriculture in Krakow and to Dr. Janusz Watroba from StatSoft Polska in Krakow forstatistical advice. The authors appreciate the suggestions of an anonymous reviewer, which significantly improved the quality of the manuscript.

\section{Compliance with ethical standards}

Conflict of interest The authors declare that they have no conflict of interest.

Open Access This article is licensed under a Creative Commons Attribution 4.0 International License, which permits use, sharing, adaptation, distribution and reproduction in any medium or format, as long as you give appropriate credit to the original author(s) and the source, provide a link to the Creative Commons licence, and indicate if changes were made. The images or other third party material in this article are included in the article's Creative Commons licence, unless indicated otherwise in a credit line to the material. If material is not included in the article's Creative Commons licence and your intended use is not permitted by statutory regulation or exceeds the permitted use, you will need to obtain permission directly from the copyright holder. To view a copy of this licence, visit http://creativecommons.org/licenses/by/4.0/.

\section{References}

Ábrahám R (2008) Thrips species associated with soybean in Hungary. Acta Phytopathol Entomol Hung 43(2):211-218. https://doi. org/10.1556/APhyt.43.2008.2.1

Allan AA, Gillet-Kaufman JL (2018) Attraction of thrips to colored sticky traps in a Florida olive grove. Fla Entomol 101(1):61-68. https://doi.org/10.1653/024.101.0112

Allsopp E (2010) Seasonal occurrence of western flower thrips, Frankliniella occidentalis (Pergande), on table grapes in the Hex River Valley, South Africa. SAJEV 3:49-57. https://doi.org/10.21548 131-1-1400

Atakan E, Canhilal R (2004) Evaluation of yellow sticky traps at various heights for monitoring cotton insect pest. J Agric Urban Entomol 21(1):15-24. https://doi.org/10.1603/en10201

Bálint J, Nagy BV, Fail J (2013) Correction: correlations between colonization of onion thrips and leaf reflectance measures across six cabbage varieties. PLoS ONE. https://doi.org/10.1371/annotation /225fb043-04ec-4bc1-91d7-ed4c49ab3dc7

Blumthal MR, Cloyd RA, Spomer LA, Warnock DF (2005) Flower color preferences of western flower thrips. Hort Technol 15(4):846-853. https://doi.org/10.21273/HORTTECH.15.4.0846

Brødsgaard HF (1989) Coloured sticky traps for Frankliniella occidentalis (Pergande) (Thysanoptera, Thripidae) in glasshouses. J Appl Entomol 107(1-5):136-140. https://doi. org/10.1111/j.1439-0418.1989.tb00240.x

Broughton S, Harrison J (2012) Evaluation of monitoring methods for thrips and the effect of trap colour and semiochemicals on sticky trap capture of thrips (Thysanoptera) and beneficial insects (Syrphidae, Hemerobiidae) in deciduous fruit trees in Western Australia. Crop Prot 42:156-163. https://doi.org/10.1016/j.cropr o.2012.05.004

Childers CC, Brecht JK (1996) Colored sticky traps for monitoring Frankliniella bispinosa (Morgan) (Thysanoptera: Thripidae) during flowering cycles in citrus. J Econ Entomol 89(5):1240-1249. https://doi.org/10.1093/jee/89.5.1240

Cho K, Eckel CS, Walgenbach JF, Kennedy GG (1995) Comparison of colored sticky traps for monitoring thrips populations (Thysanoptera: Thripidae) in staked tomato fields. J Entomol Sci 30(2):176190.https://doi.org/10.18474/0749-8004-30.2.176 
Chu CC, Pinter PJ, Henneberry TJ, Umeda K, Natwick ET, Wei YA, Reddy WR, Shrepatis M (2000) Use of CC traps with different trap base colors for silverleaf whiteflies, (Homoptera: Aleurodidae), thrips (Thysanoptera: Thripidae), and leafhoppers (Homoptera: Cicadelidae). J Econ Entomol 939(4):1329-1337. https://doi.org/10.1603/0022-0493-93.4.1329

Demirel N, Cranshaw W (2005) Attraction of color traps to thrips species (Thysanoptera: Thripidae) on Brassica crops in Colorado. Pak J Biol Sci 8(9):1247-1249. https://doi.org/10.3923/ pjbs.2005.1247.1249

Diaz-Montano J, Fail J, Deutschlander M, Nault BA, Shelton AM (2012) Characterization of resistance, evaluation of the attractiveness of plant odors, and effect of leaf color on different onion cultivars to onion thrips (Thysanoptera: Thripidae). J Econ Entomol 105(2):632-641. https://doi.org/10.1603/EC112 33

Feller C, Bleiholder H, Buhr L, Hack H, Hess M, Klose R, Meier U, Strauss R, Van den Boom T, Weber E (1995) Phänologische Entwicklungsstadien von Gemüsepflanzen II. Fruchtgemüseund Hülsenfrüchte. Nachrichtenbl Deut Pflanzenschutzd 47(9):217-232

Ferrarezi RS, Weiss SA, Geiger TC, Beamer KP (2016) Edible-pod peas as high-value crops in the US Virgin Islands. Hort Technol 26(5):683-689. https://doi.org/10.21273/HORTTECH03438-16

Gaskel M (1997) Eddible-pod pea production in California. University of California. Division of Agricultural and Nature Resources. Publication 7233, https://anrcatalog.ucanr.edu/pdf/7233.pdf

Gharekhani GH, Ghorbani A, Saber M, Bagheri M (2014) Influence of the colour and height of sticky traps in attraction of Thrips tabaci (Lindeman) (Thysanoptera, Thripidae) and predatory thrips of family Aeolothripidae on garlic, onion and tomato crops. Arch Phytopathol Plant Protect 47(18):2270-2275. https://doi. org/10.1080/03235408.2013.874100

Hoddle MS, Robinson L, Morgan D (2002) Attraction of thrips (Thysanoptera: Thripidae and Aeolothripidae) to colored sticky cards in a California avocado orchard. Crop Prot 21(5):383-388. https ://doi.org/10.1016/S0261-2194(01)00119-3

Jenser G, Szénási Á, Zana J (2001) Investigation on the colour preference of Thrips tabaci Lindeman (Thysanoptera: Thripidae). Acta Phytopathol Entomol Hung 36:207-211. https://doi.org/10.1556/ APhyt.36.2001.1-2.25

Kahrer A (1992) Monitoring the timing of peak flight activity of Thrips tabaci in cabbage fields. Bull OILB SROP (France) 15:28-35

Kirk WDJ (1984) Pollen feeding in thrips (Insecta: Thysanoptera). J Zool 204(1):107-117. https://doi.org/10.1111/j.1469-7998.1984. tb02364.x

Koschier EH, Sedy KA, Novak J (2002) Influence of plant volatiles on feeding damage caused by the onion thrips Thrips tabaci. Crop Prot 21(5):419-425. https://doi.org/10.1016/S0261 -2194(01)00124-7

Laubertie EA, Wratten SD, Sedcole JR (2006) The role of odour and visual cues in the pan-trap catching of hoverflies (Diptera: Syrphidae). Ann Appl Biol 148(2):173-178. https://doi.org/10.111 1/j.1744-7348.2006.00046.x

Lewis T (1997) Pest thrips in perspective. In: Lewis T (ed) Thrips as crop pests. University Press, CAB International, Cambridge, pp $1-14$

Lim UT, Mainali BP (2009) Optimum density of chrysanthenum flower model traps to reduce infestation of Frankliniella intonsa (Thysanoptera: Thripidae) on greenhouse strawberry. Crop Prot 28(12):1098-1100. https://doi.org/10.1016/j.cropro.2009.07.012

Liu TX, Chu CC (2004) Comparison of absolute estimates of Thrips tabaci (Thysanoptera: Thripidae) with field visual counting and sticky traps in onion field in South Texas. Southwest Entomol 29(2):83-89
Maredia KM, Gage SH, Landis DA, Wirth TM (1992) Visual response of Coccinella septempunctata (L.), Hippodamia parenthesis (Say), (Coleoptera: Coccinellidae), and Chrysoperla carnea (Stephens), (Neuroptera: Chrysopidae) to colors. Biol Cont 2(3):253256. https://doi.org/10.1016/1049-9644(92)90067-N

Mateus C, Mexia A (1995) Western flower thrips response to color. In: Parker BL, Skinner M, Lewis T (eds) Thrips biology and management. Plenum Press, New York, pp 567-570

Moreno DS, Gregory WA, Tanigoshi LK (1984) Flight response of Aphytismeliotus (Hymenoptera: Aphelinidae) and Scirothrips citri (Thysanoptera: Thripidae) to trap color, size and shape. Environ Entomol13(4):935-940. https://doi.org/10.1093/ee/13.4.935

Mueva AM, Waiganjo AA, Kutima HL, Osiemo Z, Nyasani JO, Subramanian S (2014) Attraction of pest thrips (Thysanoptera: Thripidae) infesting French beans to coloured sticky traps with Lurem TR and its utility for monitoring thrips populations. J Trop Insect Sci 34(3):197-206. https://doi.org/10.1017/S174275841400040X

Natwick ET, Byers JA, Chu CC, Lopez M, Henneberry TJ (2007) Early detection and mass trapping of Frankliniella occidentalis and Thrips tabaci in vegetable crops. Southwest Entomol 32(4):229 238. https://doi.org/10.3958/0147-1724-32.4.229

Otieno JA, Stukenberg N, Weller J, Poehling HM (2018) Efficacy ofLED-enhanced blue sticky traps combined with the synthetic lure Lurem-TR for trapping of western flower thrips (Frankliniella occidentalis). J Pest Sci 91:1301-1314. https://doi.org/10.1007/ s10340-018-1005-x

Pobozniak M (2013) The species composition, harmfulness and selected aspects of the occurrence and feeding preference of thrips (Thysanoptera) on pea (Pisum sativum L.) cultivars. Zesz Nauk UR w Krakowie, Rozprawy 391

Pobozniak M, Swiderski A (2011) Initial research on the influence of the colour of the pea leaves on the infestation by thrips. Ecol Chem Eng A 18:83-88

Rőth F, Galli Z, Tóth M, Fail J, Jenser G (2016) The hypothesized visual system of Thrips tabaci Lindeman and Frankliniella occidentalis (Pergande) based on different coloured traps' catches. North-West J Zool 12(1):40-49

Sahito HA, Arain MB, Mal B, Channa MS, Dhiloo KH (2013) Efficacy of different insecticides against thrips on peas, Pisum sativum (L.) in vivo condition. Int J Agr Sustain 3(1):56-77

Seo M, Kim S, Kang E, Kang M, Yu Y, Nam M, Jeong S, Youn Y (2006) Attraction of the garden thrips, Frankliniella intonsa (Thysanoptera: Thripidae), to colored sticky cards in a Nonsan strawberry greenhouse. Korean J Appl Entomol 45(1):37-43

Shelton AM, North RC (1987) Injury and control of onion Thrips (Thysanoptera: Thripidae) on edible podded peas. J Econom Entomol 80(6):1325-1330. https://doi.org/10.1093/jee/80.6.1325

Shelton AM, Zhao JZ, Nault BA, Plate J, Musser FR, Larentzaki E (2006) Patterns of insecticide resistance in onion thrips (Thysanoptera: Thripidae) in onion fields in New York. J Econ Entomol 99(5):1798-1804. https://doi.org/10.1093/jee/99.5.1798

Strassenzur R (2003) Die terebranten Thysanopteren Europas. Die Tierwelt Deutschlands, 74, Goecke and Evers, Keltern

Symporien A, Karungi J, Odong TL, Badji A, Kumi F, Mwila N, Rubaihayo PR (2018) Biochemical constituents influencing the resistance to flower bud thrips in cowpea [Vignaunguiculata $(\mathrm{L}$. Walp] germplasm. J Anim Plant Sci 28(1):128-137

Teulon DAJ, Penman DR (2012) Colour preferences of New Zealand thrips (Terebrantia: Thysanoptera). N Z Entomol 15(1):8-13. https ://doi.org/10.1080/00779962.1992.9722621

Trdan S, Andjus L, Raspudić E, Kač M (2005a) Distribution of Aeolothripsintermedius Bagnall (Thysanoptera: Aeolothripidae) and its potential prey Thysanoptera species on different cultivated host plants. J Pest Sci 78(4):217-226. https://doi.org/10.1007/s1034 0-005-0096-3 
Trdan S, Valić N, Žezlina K, Bergant K, Žnidarćić D (2005b) Light blue sticky boards for mass tramping of onion thrips, Thripstabaci Lindeman (Thysanoptera: Thripidae) in onion crops: fact or fantasy? J Plant Dis Protect 112(2):173-180

Weber E, Bleiholder H (1990) Erläuterungenzu den BBCH-DezimalCodes für die Entwicklungsstadien von Mais, Raps, Faba-Bohne, Sonnenblume und Erbse. GesundePflanz 42:308-321

Zawirska I. (1994) Thrips (Thysanoptera). In. Kozłowski MW, Boczek J (ed) Diagnostics of plant pests and their natural enemies. SGGW, Warszawa, Poland, pp 145-174
Publisher's Note Springer Nature remains neutral with regard to jurisdictional claims in published maps and institutional affiliations. 